\title{
My Improbable Mentor Quotes Osler
}

\author{
Mary F. Morrison ${ }^{1}$
}

Received: 11 November 2019 / Accepted: 10 December 2019/Published online: 2 January 2020

(C) Academic Psychiatry 2020

When you first see them, do you know who will be your mentor and change your life?

I did not recognize him then.

I am a tired medical intern wearing faded green scrubs that are too big (scrubs weren't made for women then), talking to a nurse on an inpatient unit. No coffee yet. What are we going to do about our patient? She is thirsty - thirsty in a way I have never seen before. She is searching all over her hospital room, looking for liquid to drink. We had to lock the bathroom when we caught her proceeding to drink from the toilet. How are we going to help this polydipsic woman? I feel powerless before her turbo-charged thirst.

Then he appears, upright in his posture. Military background? He is in the room talking with my patient, looking every bit the calm, wise psychiatric consultant. He knows how to connect with this pressured woman. He can interpret her language. To me, the beleaguered medical intern, she is speaking gibberish, but her words connect and have meaning to him. Is there sunlight peeking into the room now? Consultation psychiatry seems miraculous. We determine that she has psychogenic polydipsia and a new diagnosis of schizophrenia. We now have an effective treatment plan and she gets better.

My mentor-to-be becomes my teacher, as I refocus my career. I am an internist who is learning to be a psychiatrist. I can resuscitate people with lethal arrhythmias. I do that well. He shows me the way to sit with a patient who has a large, black emptiness inside. This patient fabricates an illness. Her fabrication is elaborate and compelling. I struggle to understand her captivating talents and treacherous inner world. My mentor helps me grasp my painful response to being her physician. Sustaining my cheerful self, while healing lethal inside-darkness, will take longer to learn than arrhythmia care.

Mary F. Morrison

mary.morrison@tuhs.temple.edu

1 Lewis Katz School of Medicine, Temple University, Philadelphia, PA, USA
My mentor is my boss, and I am an academic attending! I want to study depression in older women. I am pregnant, with my much wanted first child. No one has been pregnant in the department for decades. No one knows what to do with a pregnant, aspiring clinician-scientist. My mentor covers my clinical responsibilities, as well as his own, and I write. The day I submit the grant is my due date, and a day later, I have a new son. Six weeks later, my mentor helps to cover my professional responsibilities as I ease back into my two full time jobs.

I get my grant and I am NIH funded! My happy situation takes me away from my mentor. While research goes well, the nourishing environment I had with my mentor is lacking. I find I must leave academic medicine for a while. Working in clinical research in the pharmaceutical industry changes our relationship and we are close again. Once a month, I volunteer at the psychosomatic medicine outpatient clinic. For me, it is a treasured time. Together, we see complicated outpatients and teach residents. It is what we love doing together. We laugh, tell jokes and talk about the books we are reading.

I am back in academic medicine, and the decades roll by. It is hard to know how to honor an esteemed mentor. He is a modest man. However, he agrees to a portrait. He now has a portrait that reflects his dignity and professionalism. I know he likes it. The portrait also comes at the same time as a threatening medical diagnosis. I like to think that it contributed to his resilience. This summer he sent me a book that he wrote on consultation liaison psychiatry [1]. On page 15 , he has a much-loved quote from William Osler about the attributes of an excellent physician, "availability, affability, and ability...in that order." Like Osler, my mentor is a beloved clinician whose teaching approach begins with the initial contact with the patient and ends with the patient. Also, to paraphrase Osler [2], he has developed a sense of equanimity that allows for success with humility and the affection of friends without pride.

This past weekend, we shared a lovely meal together, wine glasses clinking frequently, overlooking the dashing Delaware River. A hidden chapter is clarified, how an aspiring surgeon 
became a psychiatrist. About to be drafted to Vietnam while a surgical intern, he was sitting in the hospital cafeteria with his head in his hands, looking upset. The Psychiatry chair spotted him and said that if my mentor was willing to switch to Psychiatry, he could have his service deferred during his residency. The surgeon transmuted and a Psychiatrist was recruited!

What if I had failed to notice him years ago, missed his encouragement and friendship? Mentors can appear as unlikely figures and stay with you, cherished, for the rest of your life.

Acknowledgments This piece is written in recognition of James L. Stinnett, MD, Emeritus Professor of Psychiatry, Perelman School of Medicine, University of Pennsylvania, an exemplary educator and mentor. The author would like to thank Michael Vitez, Director of Narrative
Medicine, Lewis Katz School of Medicine at Temple University, for thoughtful review. An earlier version of this piece was presented at the Lewis Katz School of Medicine Story Slam in Philadelphia, PA on October 16, 2019.

\section{References}

1. Stinnett JL. The handbook of consultation psychiatry: a roadmap to psychiatry in the general hospital. Philadelphia, PA: Self-published; 2018.

2. Cushing $\mathrm{H}$. The life of sir William Osler-volume 1. Hamburg: Severus Verlag; 2010. p. 682.

Publisher's Note Springer Nature remains neutral with regard to jurisdictional claims in published maps and institutional affiliations. 